\title{
Current status and future directions in the management of chronic hepatitis $C$
}

Wosen Aman', Shaymaa Mousa, Gamal Shiha² and Shaker A Mousa ${ }^{1 *}$

\begin{abstract}
Hepatitis $\mathrm{C}$ virus (HCV) is endemic worldwide, and it causes cirrhosis and other complications that often lead to death; nevertheless, our knowledge of the disease and its mechanisms is limited. HCV is most common in underdeveloped nations, including many in Africa and Asia. The virus is usually transmitted by parenteral routes, but sexual, perinatal, and other types of transfer have been known to occur. Approximately $80 \%$ of individuals who contract hepatitis $C$ develop a chronic infection, and very few are able to spontaneously clear the virus. Because hepatitis $C$ is asymptomatic in the majority of patients, the presence of HCV RNA in the serum is the best diagnostic tool. Although serious complications from hepatitis $C$ may not occur for 20 years, 1/5 of chronic patients eventually develop life - threatening cirrhosis. More research is needed on the different therapy options for the disease, and many factors, most importantly the genotype of the virus, must be taken into account before beginning any treatment. As there is no vaccine against HCV at present, the most effective and recommended therapy is pegylated-interferon- $\alpha$-2a plus ribavirin. While interferon is marginally effective as a monotherapy, both adding the moiety and combining it with ribavirin have been shown to dramatically increase its potency. While there are numerous alternative and complementary medicines available for patients with hepatitis $C$, their efficacy is questionable. Currently, research is being done to investigate other possible treatments for hepatitis $C$, and progress is being made to develop a vaccine against $\mathrm{HCV}$, despite the many challenges the virus presents. Until such a vaccination is available, prevention and control methods are important in containing and impeding the spread of the virus and mitigating its deleterious effects on the health of people and communities worldwide.
\end{abstract}

Keywords: Hepatitis C, Fibrosis, Cirrhosis, Hepatic carcinoma, Prevention, Treatment, Antiviral

\section{Introduction}

The hepatitis $\mathrm{C}$ virus (HCV) infects up to 170 million people throughout the world, causing chronic liver disease, inflammation, and long-term complications [1-3]. $\mathrm{HCV}$ is a member of the Flaviviridae family, has singlestranded RNA, and is relatively small (55 nm - $65 \mathrm{~nm}$ ) [1-4]. In 1989, it was determined that $\mathrm{HCV}$ is responsible for most transfusion-associated non-A and non-B hepatitis infections [2,5]. Eleven different genotypes of the virus have been identified, each with various subtypes and strains, but $60 \%$ of HCV infections are caused by type $1 \mathrm{a}$ and type $1 \mathrm{~b}[1,5]$. The majority of those exposed to $\mathrm{HCV}$ become chronic carriers of the virus; only $20 \%-30 \%$ are expected to be free of the virus within six months of

\footnotetext{
* Correspondence: Shaker.mosua@acphs.edu

'The Pharmaceutical Research Institute, Albany College of Pharmacy and Health Sciences, Rensselaer, NY, USA

Full list of author information is available at the end of the article
}

infection $[1,3,6]$. Nearly $20 \%$ of chronic carriers develop cirrhosis, while another 20\% develop liver cancer [1], (Figure 1). HCV is also the leading cause of hepatocellular carcinoma and cirrhosis [5].

\section{Acute and chronic hepatitis C}

The severity of hepatitis $C$ ranges from mild, short-term symptoms to complicated, life-long liver disease that can result in death. Whether the infection is acute or becomes chronic depends on the duration of the virus' existence in the patient's body.

Acute hepatitis $\mathrm{C}$ is a short-term infection of the virus that occurs during the first six months after exposure to $\mathrm{HCV}$. The acute stage of the disease is characterized by elevated serum alanine aminotransferase (ALT) levels and jaundice, which appears in about $25 \%$ of cases $[1,5,7]$. About $80 \%$ of acute hepatitis $C$ cases are asymptomatic, and are therefore difficult to diagnose $[5,8]$. However, if a

\section{Biomed Central}




\section{Progression of $\mathrm{HCV}$ infection}

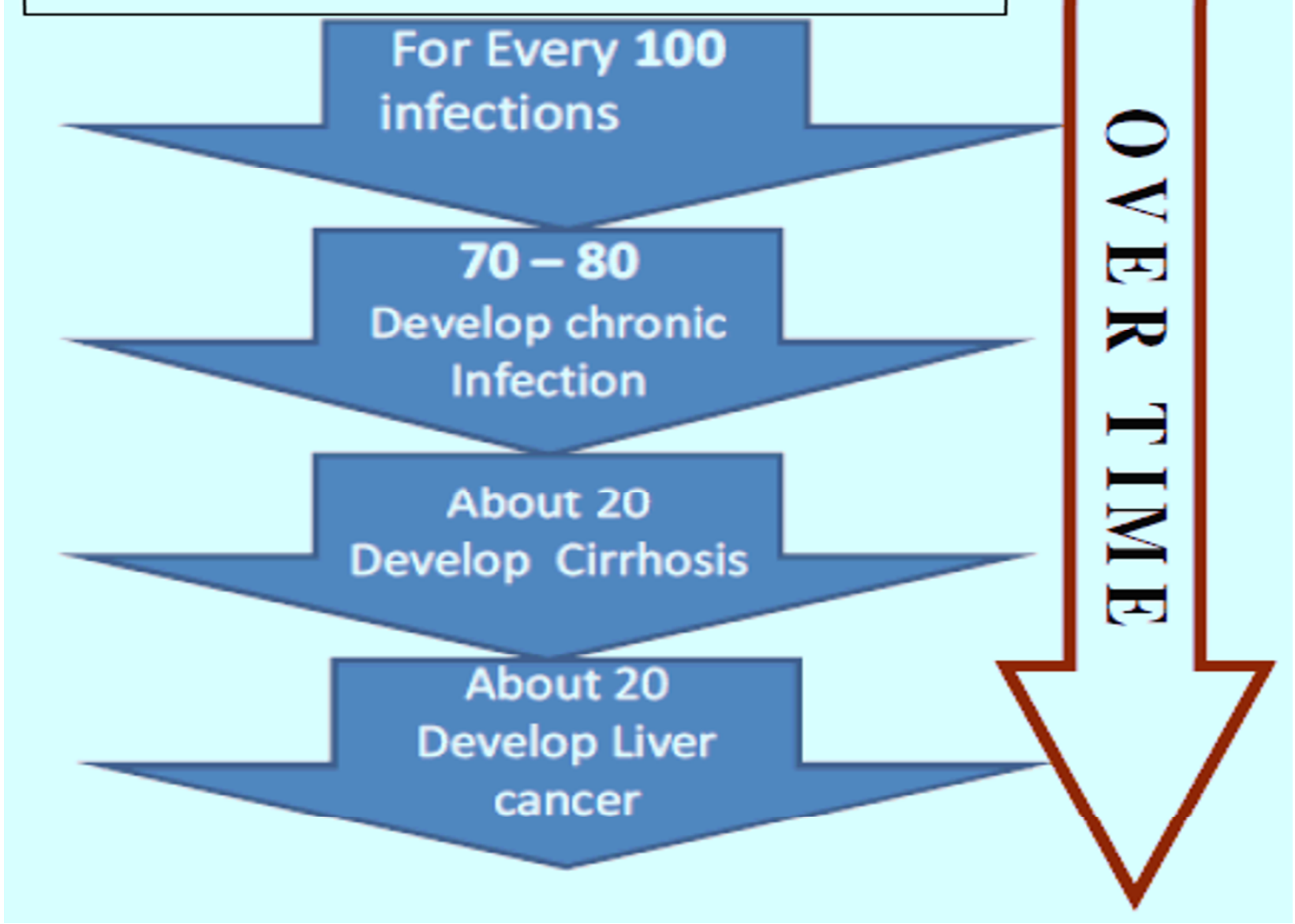

Figure 1 Progression of HCV Infection.

patient's symptoms and/or lifestyle are suggestive of an $\mathrm{HCV}$ infection, they should be tested for the disease. The presence of HCV RNA in the serum is the most reliable way to diagnose hepatitis $\mathrm{C}$, but the presence of anti-HCV antibodies in the serum or an elevated serum ALT level (a concentration at least ten times the upper limit of the normal range is necessary for a diagnosis) can also indicate an HCV infection $[1,3,5,7]$. The remaining $20 \%$ of cases are symptomatic, and are characterized by poor appetite, abdominal pain in the right upper quadrant, joint and muscle pains, nausea, vomiting, and fever $[1,3,5,7]$. However, because these symptoms are common and inconclusive, symptomatic hepatitis $C$ should be diagnosed by the same tests used to confirm an asymptomatic infection.

An acute hepatitis $\mathrm{C}$ infection becomes a chronic disease if the individual is unable to clear the virus from their system within six months of infection without any therapeutic intervention; approximately $70 \%-80 \%$ of those with an acute infection develop chronic hepatitis $C[1,5,6]$. Chronic hepatitis $\mathrm{C}$ is officially diagnosed by the presence of anti$\mathrm{HCV}$ and the elevation of serum ALT levels for more than six months [3]. Even in the chronic stage, however, most infected persons show no symptoms until serious complications arise, although this often does not occur until 20 years after infection $[1,3,5]$. As such complications including hepato-cellular carcinoma, liver failure, and cirrhosis - develop as the infection progresses, more prominent symptoms such as swelling of the abdomen, fatigue, dark urine, fluid retention, jaundice, ascites, muscle weakness, itching, and weight loss are observed [3,5]. Cirrhosis is perhaps the most well known consequence of chronic hepatitis $C$, and occurs in about $20 \%$ of patients $[1,5]$. About 20\% - 25\% of patients who do develop cirrhosis as a result of $\mathrm{HCV}$ die from liver failure [5].

\section{Treatment of hepatitis C}

The goal of hepatitis $C$ treatment is to prevent the development of chronic infection, increase the patient's 
quality of life, and prevent morbidity and mortality [9]. However, the type and duration of therapy a patient receives depends on a number of factors, including age, the genotype of the virus, and any previous conditions the patient may have. For example, individuals with decompensated cirrhosis, severe uncontrolled psychiatric disorders, advanced cardiovascular or cerebrovascular disease, creatinine clearance of less than $50 \mathrm{~mL} / \mathrm{min}$, or women who are pregnant should not receive therapy $[3,9,10]$. Additionally, more research is needed on the proper treatment protocol for children, which is likely different than that for adults [11,12].

So far, $11 \mathrm{HCV}$ genotypes have been discovered, but only genotypes 1, 2 and 3 are distributed worldwide, and about $60 \%$ of infections are due to type $1 \mathrm{a}$ and $1 \mathrm{~b}$ $[1,5]$. The genotype of the virus plays a substantial role in determining the duration and type of treatment the patient receives (viral load of serum is the other main factor to consider); thus it is necessary to confirm the genotype of a specific infection in order to plan an appropriate therapeutic strategy $[2,3,5]$. Although all genotypes exhibit relatively equal virulence, they differ in their response to a given medication [1-5]. In general, any treatment involving Interferon (IFN) is more effective against HCV genotype 2 and 3 than against genotype 1 , which is less responsive to therapy [1-5]. Thus, a 48-week course of treatment is recommended for genotype 1 , whereas a 24-week therapy is sufficient for genotypes 2 and $3[2,3,5]$.

\section{Non-pharmacologic treatments}

After a patient is diagnosed with hepatitis C, lifestyle changes must be made in order to limit and control further health problems. These non-pharmacologic treatments include engaging in regular physical exercise, adopting healthy eating habits, and maintaining a healthy weight. The latter is especially important, because it is believed that obesity in HCV patients plays a significant role in the progression of fibrosis [13,14]. Also, patients should avoid drinking alcohol because there is no safe minimum limit of consumption, and alcohol is one of the major risk factors for liver disease and exacerbates the negative effects of hepatitis $C$ $[3,15,16]$. Additionally, hepatitis $C$ patients are advised not to smoke because smoking may contribute to the progression of the disease and increase the likelihood of developing hepatocellular carcinoma $[9,17]$.

\section{Pharmacologic treatments}

Most cases (72\%-98\%) of symptomatic acute hepatitis C are curable if diagnosed early [18]. However, because some patients with symptomatic HCV may spontaneously clear the virus from their systems within 12 weeks of infection, therapy should not begin until after this time period has elapsed in order to avoid unnecessary treatment and medical costs $[8,18-20]$. On the other hand, because relatively few individuals with asymptomatic acute hepatitis $\mathrm{C}$ are able to spontaneously clear the virus, in such cases the appropriate treatment should be initiated as soon as possible $[18,20]$. However, the rate of spontaneous clearance is debatable; some sources indicate that around $31 \%$ of symptomatic cases and about $18 \%$ of asymptomatic cases are naturally resolved without treatment [18], while others suggest higher figures. A study by Geralch et al., for instance, showed that permanent and spontaneous clearance of the virus was observed in more than $50 \%$ of untreated patients with acute symptomatic $\mathrm{HCV}$ within the first three to four months after infection [20]. Those who remained infected after that time period were treated with either IFN-monotherapy, or with IFN plus ribavirin, and about $80 \%$ of those patients showed a sustained biochemical and virological response. Initiating treatment in patients with acute symptomatic $\mathrm{HCV}$ three months after infection led to viral clearance in $91 \%$ of the patients as a result of both spontaneous clearance and anti-viral treatment [20]. Regardless of the exact figures, there is a general consensus that asymptomatic patients should begin receiving treatment immediately, while symptomatic patients may benefit from postponing therapy for several months.

\section{Pegylated interferon-alpha monotherapy}

The covalent attachment of a polyethylene glycol (peg) moiety to IFN- $\alpha$ reduces the clearance and degradation of the drug, thus sustaining a high plasma concentration and prolonging the half-life of the compound, respectively $[2,3]$. There are currently two versions of this compound known as pegylated interferon (peg-IFN) being used to treat hepatitis C: peg-IFN- $\alpha-2 \mathrm{a}$ and pegIFN- $\alpha-2 b$. Common side effects of peg-IFN- $\alpha$ treatment include headache, fatigue, depression, insomnia, fever, nausea, myalgia, weakness, hematologic disorder, and injection site reaction [21]. Studies show that a once weekly administration of peg-IFN- $\alpha-2 \mathrm{a}$ is more efficient than a regimen of IFN- $\alpha-2 \mathrm{a}[22-24]$. A comparison between the clinical effects of a regimen of peg-IFN- $\alpha$ $2 a$ and a regimen of IFN- $\alpha-2 a$ was made in the study by Zeuzem et al. (Table 1). The results show a profound improvement in both virology and biochemical responses after 48 and 72 weeks [22].

\section{Peg-IFN- $\alpha-2 a$ versus Peg-IFN- $\alpha-2 b$}

The FDA has approved both pegasys (peg-IFN- $\alpha-2 \mathrm{a}$ ) and PEG-Intron (peg-IFN- $\alpha-2 b$ ) for use as monotherapies and in combination for the treatment of chronic $\mathrm{HCV}$ in patients with compensated liver disease who have not been treated previously. Some of the 
Table 1 A summary of the effects of Peg-IFN- $\alpha-2 a$ vs. IFN- $\alpha-2 a$. From Zeuzem et al. [22].

\begin{tabular}{|c|c|c|c|c|}
\hline \multirow[t]{4}{*}{ End of Treatment Response } & \multicolumn{2}{|c|}{ Peg-IFN- $\alpha-2 a$ Group } & \multicolumn{2}{|c|}{ IFN- $\alpha-2 a$ Group } \\
\hline & \multicolumn{2}{|c|}{ No. Patients completed treatment $=223$} & \multirow{2}{*}{\multicolumn{2}{|c|}{ No. Patients completed treatment $=161$}} \\
\hline & \multicolumn{2}{|c|}{ No. Patients completed follow-up $=206$} & & \\
\hline & No. & $\%(95 \% \mathrm{Cl})$ & No. & $\%(95 \% \mathrm{Cl})$ \\
\hline \multicolumn{5}{|c|}{ Response at week 48} \\
\hline Virological & 185 & $69(63-75)$ & 73 & $28(22-33)$ \\
\hline Biochemical & 123 & $46(40-52)$ & 104 & $39(33-46)$ \\
\hline Both virological and biochemical & 109 & $41(35-47)$ & 65 & $25(20-30)$ \\
\hline \multicolumn{5}{|c|}{ Response at week 72} \\
\hline Virological & 103 & $39(33-45)$ & 50 & $19(14-24)$ \\
\hline Biochemical & 120 & $45(39-51)$ & 65 & $25(20-30)$ \\
\hline Both virological and biochemical & 101 & $38(32-44)$ & 46 & $17(13-23)$ \\
\hline
\end{tabular}

differences between the two drugs are summarized in Table 2.

\section{Ribavirin}

Ribavirin is a synthetic nucleoside antagonist that is active against a broad range of viruses [27,28]. It hinders the initiation and elongation of RNA fragments by inhibiting the synthesis of viral proteins [4,28]. However, the mechanism by which it inhibits HCV RNA in combination therapy with interferon products has not been established $[4,11]$. Using ribavirin alone as a monotherapy for hepatitis $\mathrm{C}$ is not recommended, as other treatments (including ribavirin combined with interferon) are more effective [29-32].

The results of a randomized, double blind, placebocontrolled study conducted to evaluate the role of ribavirin in the treatment of chronic hepatitis $C$ showed that ribavirin monotherapy, given for periods as long as 12 months, is of limited use as a therapy for chronic hepatitis $C$. In this study, a rapid decrease in serum aminotransferase levels was observed in $54 \%$ of patients who were treated with ribavirin. However, only $7 \%$ of patients had normal levels of aminotransferase after the discontinuation of ribavirin and there was no change in the serum HCV RNA levels during or after the treatment, proving that the therapy is ineffective [29]. The outcome of a study by Dusheiko et al. indicates that there was no difference between the treatment group and the placebo group in the reduction of HCV RNA levels six months after ribavirin therapy was discontinued. As a result, they concluded that ribavirin was no more effective than a placebo in the treatment of $\mathrm{HCV}$ [30].

Also, ribavirin has several adverse side effects that make it less preferable over other treatments [32]. For example, hemolytic anemia is a common consequence of ribavirin use, but a lower, less-effective dose of the drug may be necessary to reverse the reduction of hemoglobin values [9,32]. Other frequent side effects of ribavirin include pruritus, rash, indigestion, loss of appetite, nausea, headache, and fatigue [11,32].

\section{Pegylated interferon and ribavirin}

The highest sustained virologic response (SVR) in patients with hepatitis $C$ has been achieved by a treatment combining peg-IFN $-\alpha-2 \mathrm{a}$ and ribavirin. This combination therapy has thus become the current standard of care for patients with chronic hepatitis $\mathrm{C}$ who have not been treated previously [33].

The findings of a large randomized clinical trial of 1530 patients with chronic hepatitis C show a

Table 2 A comparison of Peg-IFN- $\alpha-2 a$ and Peg-IFN- $\alpha-2 b$

\begin{tabular}{llll}
\hline Size & Peg-IFN- $\boldsymbol{\alpha}$-2a & Peg-IFN- $\boldsymbol{\alpha}$-2b & Remark \\
\hline Common Dose & $\begin{array}{l}\text { Large polyethylene } \\
\text { glycol moiety }\end{array}$ & $\begin{array}{l}\text { Relatively small polyethylene } \\
\text { glycol moiety } \\
\text { subcutaneously }\end{array}$ & $\begin{array}{l}\text { Polyethylene glycol moiety in Peg-IFN- } \alpha \text {-2a is twice the size of } \\
\text { that in Peg-INF- } \boldsymbol{\alpha}-2 \mathrm{~b}[9] .\end{array}$ \\
\hline Efficacy* & Worse & Better & \\
\hline $\begin{array}{l}\text { Infant and } \\
\text { Neonatal use }\end{array}$ & Contraindicated & Safe & Peg-IFN- $\alpha$-2a contains benzyl alcohol [9].
\end{tabular}

*The results of a randomized trial suggested that, despite its relatively short half-life, Peg-IFN- $\alpha-2 b$ results in a greater decrease in HCV RNA than Peg-IFN- $\alpha$-2a during the first four weeks of monotherapy [25]. However, there was no difference observed between Peg-IFN- $\alpha-2 b$ plus ribavirin and Peg-IFN- $\alpha-2 a$ plus ribavirin in the treatment of chronic hepatitis C in HIV-infected patients [26] 
significantly higher SVR in the peg-IFN- $\alpha-2 b$ plus ribavirin group than in the IFN- $\alpha-2 b$ plus ribavirin group during initial treatment [34]. This study also established the dose-dependent nature of peg-IFN: a higher dose $(1.5 \mathrm{~g} / \mathrm{kg})$ of peg-IFN given once weekly in combination with ribavirin is more effective than the lower dose $(0.5$ $\mathrm{g} / \mathrm{kg}$ ) administered by the same protocol. Patients given the lower dose also showed a response similar to that of the patients who received a standard dose of IFN- $\alpha-2 b$ plus ribavirin. Table 3 summarizes the outcomes of the various treatment groups. Adverse effects were similar in both the peg-IFN- $\alpha-2$ b plus ribavirin group and in the IFN- $\alpha-2 b$ plus ribavirin group [34].

A randomized, double blind trial with 1311 participants was conducted to assess the efficacy and safety of 24 versus 48 weeks of treatment with peg-IFN- $\alpha-2 \mathrm{a}$ a plus a low or standard dose of ribavirin [35]. The results showed that the duration of treatment using peg-IFN- $\alpha$ $2 \mathrm{a}$ and ribavirin should be determined based on the $\mathrm{HCV}$ genotype. According to this study, HCV genotype 1 is best treated by a 48 -week regimen of $180 \mu \mathrm{g} / \mathrm{wk}$ of peg-IFN- $\alpha-2 \mathrm{a}$ and a standard, weight-based dose (1000 or $1200 \mathrm{mg} / \mathrm{d}$ ) of ribavirin. Another study showed that a low vitamin D serum level is associated with low response rates and severe fibrosis in genotype 1 [36]. Therefore, Vitamin D supplementation may increase sustained response to pegylated interferon plus ribavirin [37]. HCV genotypes 2 and 3 can be treated adequately with a 24-week regimen of $180 \mu \mathrm{g} /$ wk of peg-IFN- $\alpha-2 \mathrm{a}$ and a low-dose $(800 \mathrm{mg} / \mathrm{d})$ of ribavirin [35].

The response to therapy in HCV patients is heterozygous and, despite increases in SVR rates, treatment outcomes in certain populations with peg-IFN- $\alpha$ and ribavirin are not optimal and may still be improved $[35,38]$. Early antiviral response to therapy should be monitored to assist in identifying patients who are less likely to achieve SVR and is therefore critical in the management of $\mathrm{HCV}$ patients. Rapid virological response (RVR) and complete early virological response (cEVR) are linked with patients who achieve SVR [39]. Identifying both patient- and virus-related baseline and treatment factors that are associated with RVR and cEVR with peg-IFN- $\alpha-2$ a plus ribavirin therapy may help predict a patient's response to treatment, in addition to supplying information that can be used to enhance viral outcomes $[39,40]$. For example, adjusting baseline and/or treatment factors, such as drug dose, may increase a patient's chance of a successful response to therapy. Moreover, those patients unlikely to reach RVR or cEVR will be recognized early on and this will diminish needless healthcare expenses and side-effects. A retrospective analysis demonstrated that factors including lower serum HCV RNA concentration, absence of cirrhosis, higher ALT quotient, younger age, white non-Latino ethnicity, and daily on-treatment ribavirin dose $>13 \mathrm{mg} / \mathrm{kg}$ were independently linked with achieving RVR and cEVR in patients with HCV genotype 1 and treated with peg-IFN- $\alpha$-2a plus ribavirin for 48 weeks [41]. They recommended that physicians maintain a higher ribavirin dose in patients to increase the likelihood of achieving SVR and tailoring treatment regimens based on an individual's risk profile may be one approach to achieve optimal antiviral response.

\section{Protease inhibitors}

One of the most important determents of response to therapy is the genetic profile of the patient. Patients with a polymorphic mutation on the IL-28B gene for genotype 1 have poor response to treatment. Currently the standard for care is the combination of peg-IFN- $\alpha$ and ribavirin, but only $40-50 \%$ of patients infected with HCV genotype 1 have SVR [35]. Retreatment only achieves SVR in $10-20 \%$ of patients, but data released at the International Liver Congress shows SVR rates of 40$80 \%$ when protease inhibitors are used, even in the presence of the IL-28B genotype [42-44].

\section{Telaprevir}

Telaprevir (VX-950) is a targeted antiviral therapy for hepatitis C. This drug is administered orally and selectively and reversibly inhibits HCV NS3/4A protease, an enzyme required for viral replication. Studies show that VX-950 has a significant antiviral effect on patients with HCV genotype 1, and is well tolerated [45-47]. It has a synergistic antiviral effect when administered with IFN as demonstrated in several studies [47]. Telaprevir was FDA-approved in May, 2011 after the results of the ADVANCE trial [48]. This trial showed that telaprevir combined with standard therapy cured the virus in $75 \%$ of patients compared with $44 \%$ of patients who were

Table 3 Virological responses in the study by Manns et al. [34]

\begin{tabular}{|c|c|c|c|c|c|}
\hline \multirow[t]{2}{*}{ Groups } & \multirow[t]{2}{*}{ Overall SVR } & \multirow[t]{2}{*}{ SVR at end of follow-up } & \multicolumn{3}{|c|}{ SVR by genotype } \\
\hline & & & GT 1 & GT $2 / 3$ & GT $4 / 5 / 6$ \\
\hline Higher-dose peg-IFN + Rib & $65 \% P<0.001$ & $54 \% P=0.01$ & $42 \%$ & $82 \%$ & $50 \%$ \\
\hline Lower-dose peg-IFN + Rib & $56 \%, P=0.41$ & $47 \% P=0.73$ & $34 \%$ & $80 \%$ & $33 \%$ \\
\hline IFN + Rib & $54 \%$ & $47 \%$ & $33 \%$ & $79 \%$ & $38 \%$ \\
\hline
\end{tabular}

INF = Interferon, Rib = Ribavirin, SVR = sustained virologic response, GT = genotype. *P values are calculated for comparison with IFN + Rib 
cured on standard therapy alone. Of the almost $60 \%$ of telaprevir -treated patients who had undetectable viral levels at weeks 4 and 12 and who were eligible by the terms of the study to receive 24 weeks total of treatment - half the time required for standard treatment approximately $90 \%$ were cured. There were also substantial benefits of telaprevir in subgroups of patients who generally do not respond well to standard therapy. For example, only $25 \%$ of African-Americans treated with standard therapy achieved a viral cure compared to $62 \%$ of African-American patients who reached a viral cure with the telaprevir regimen. In another group of patients with advanced liver cirrhosis $62 \%$ achieved a viral cure with telaprevir versus $33 \%$ on standard therapy [48]. These results confirm the findings of the U.S. Phase 2 PROVE 1 study and the European PROVE 2 study [46].

\section{Boceprevir}

Boceprevir, (SCH 503034), is a peptidomimetic ketoamide HCV NS3 protease inhibitor that binds reversibly to the NS3 active site [49]. It has potential as a timedependent inhibitor of the NS3 protease in cell-free enzyme assays, and has shown robust in vitro activity in the HCV replicon system. The use of SCH 503034 in combination with IFN was more effective than either therapy alone in inhibiting viral replication [50]. Boceprevir has also been shown to minimize the emergence of resistant HCV strains when combined with the inhibitor HCV-796 [49], and was approved by the FDA in May, 2011. The HCV RESPOND-2 study looked at 403 chronic hepatitis $\mathrm{C}$ patients with genotype 1 who still had significant levels of the virus after standard treatment of peginterferon and ribavirin. Significantly more patients were cured with boceprevir than with peginterferon and ribavirin [51]. A second study, HACV SPRINT-2, examined patients with chronic HCV genotype 1 infection who had not yet undergone standard treatment, and it was found that there were significantly increased rates of sustained virologic response [52].

Although these direct anti-virals are effective in the treatment of both treatment-naïve HCV patients and those patients who were previously unresponsive to current treatment options, the development of resistant viral variants may be cause for worry. Two studies have found HCV strains resistant to these novel antiviral compounds even for patients who had never been previously exposed to the new antiviral compounds [53-55]. Each new copy of the HCV genome exhibits on average one nucleotide change per replication cycle; this allows the virus to quickly come up with mutations that render it resistant to antiviral drugs. This is a major concern for successful anti-HCV therapy [56].
A significant number of HIV patients are also infected with $\mathrm{HCV}$. With improved survival rates in the HIV population liver disease caused by HCV becomes a serious issue in the health and survival of these patients [57]. HCV patients who are co-infected with HIV have an increased risk of accelerated end stage liver disease and hepatocellular carcinoma than patients infected only with HCV. Therefore treatment should be considered a priority in this group [58]. In October, 2011 the European AIDS Clinical Society (EACS) and the American Association for the Study of Liver Diseases (AASLD) added telaprevir and boceprevir in their guidelines for HIV/HCV co-infected patients [59,60].

There are several other antiviral drugs in different phases of clinical trials. Table 4 summarizes the current drugs that are under development [61].

\section{Pharmacoeconomics of HCV Therapy}

Since the treatment of HCV with peg-IFN and ribavirin is expensive, it is necessary to evaluate the cost-effectiveness of the available treatment options. The wholesale price of a 48-week supply of peg-IFN plus ribavirin is about $\$ 30,000$, while a comparable supply of nonpegylated IFN plus ribavirin costs between $\$ 15,000$ and $\$ 20,000$ [9]. A study by Salmon et al. examined the costeffectiveness and benefits of the current treatments for a chronic hepatitis $\mathrm{C}$ infection in asymptomatic and $\mathrm{HCV}$ seropositive individuals. The outcome of the study showed that the cost of therapy depends on the genotype and the gender of the patients [62]. Another systematic review of several randomized clinical trials, reports, and meta-analyses reinforced the cost effectiveness of initial combination therapy to prolong life, and improve quality of life [63]. Generally, before beginning treatment, a thorough evaluation of the appropriateness of the therapy is needed, and all decisions regarding the treatment should be made by the patient. Malone et al. compared the costeffectiveness of treatment with peg-IFN- $\alpha-2 b$ plus ribavirin with that of peg-IFN- $\alpha-2 \mathrm{a}$ in hypothetical cohorts of 100 chronic HCV patients, $75 \%$ of whom had a genotype 1 infection [64]. According to the study, the use of peg-IFN- $\alpha-2 b$ and ribavirin may be cheaper than pegIFN- $\alpha-2 \mathrm{a}$ for the treatment of the hypothetical cohort.

New research has also determined that patients in the United States with HCV are twice as likely not to have health insurance as patients without HCV. Only a third of $\mathrm{HCV}$ infected Americans have access to antiviral therapy. The remaining patients are either not candidates for therapy owing to treatment contraindications or are uninsured [65].

\section{Future treatment options}

Despite recent advances in the treatment of chronic hepatitis $C$, the current treatment options have been 
Table 4 A summary of current Hepatitis C drugs based on proteases, polymerase, and other degrading enzymes that are in preclinical development or in clinical trials

\begin{tabular}{llll}
\hline Drug Name & Pharma Co. & Class & Clinical Trial Phase \\
\hline TMC435350 & Tibotec \& Medivir & Protease inhibitor & $\|$ \\
\hline R1626 & Roche & Nucleoside polymerase inhibitor & $\|$ \\
\hline DEBIO-025 & Debiopharm & Cyclophilin inhibitor & $\|$ \\
\hline Celgosivir & Migenix & $\alpha$-glucosidase inhibitor & $\|$ \\
\hline B112202 & Boehringer & Protease inhibitor & | \\
\hline MK-7009 & Merck & Protease inhibitor & I \\
\hline ITMN-191 & InterMune \& Roche & Protease inhibitor & I \\
\hline NIM-811 & Novartis & Cyclophilin inhibitor & I \\
\hline R7128 & Pharmasset \& Roche & Nucleoside polymerase inhibitor & I \\
\hline PSI-6130 & Pharmasset & Nucleoside polymerase inhibitor & I \\
\hline MK-0608 & Merck & Nucleoside polymerase inhibitor & Preclinical
\end{tabular}

ineffective in a significant number of patients, and there is an unmet need for novel, potent, and well-tolerated anti-HCV drugs. Currently, researchers are investigating different treatments for $\mathrm{HCV}$, with the hope of finding more effective and safer therapies; some of the potential candidates are discussed below.

\section{Cyclophilin inhibitors}

Cyclophilins are cyclosporin binding proteins and are classified as a family of peptidyl-prolyl cis-trans isomerases. These enzymes catalyze the cis-trans interconversion of peptide bonds amino-terminal to proline residues, resulting in a conformational change in the protein structure. There are more than 10 subgroups of cyclophilins in mammals [66]. Medications that inhibit these proteins may be an effective treatment against hepatitis $C$ infections. Debio 025 is a cyclophilin B (CyPB) inhibitor taken orally that blocks $\mathrm{HCV}$ replication by inhibiting $\mathrm{CyPB}$, a cellular cofactor of the NS5B RNA-dependent RNA polymerase [66]. It also has also the ability to delay or prevent $\mathrm{HCV}$ from developing resistance against other antiviral drugs [67]. SCY-635 is a non-immunosuppressive derivative of cyclophilin A that is also taken orally. In vitro studies have shown that this drug exhibits synergistic antiviral activity when administered with INF- $\alpha-2 b$ and additive antiviral activity when given with ribavirin [68].

\section{Immunomodulatory agents}

Several toll-like receptor (TLR) agonists are being investigated as possible drugs to stimulate protective antiviral immunity. A phase 1 study of CPG 10101, a synthetic oligodeoxynucleotide, demonstrated that it acts as an immunomodulator and decreases HCV RNA levels [69]. Isatoribine is a TLR7 agonist that produces a significant dose-dependent drop in plasma HCV RNA without major side effects [70].

\section{Thiazolides}

Studies have noted that thiazolides, such as nitazoxanide and tizoxanide, are potent inhibitors of HCV replication, and suggest that thiazolides may enhance current or future anti-hepatitis treatments [71-73].

\section{Vaccines}

At the present, there is not an effective vaccine against $\mathrm{HCV}$ [5], and efforts to develop a vaccine have been met with many difficulties $[1,3,5]$. The genetic diversity among the HCV genotypes makes it challenging to create a single vaccine effective against all types of the virus $[1,3,5]$, and its fast mutation rate further complicates the issue [4]. Nevertheless, findings from various studies show promising advances in the development of new immunotherapy treatments against $\mathrm{HCV}$.

\section{HCV-LP}

An animal study showed that immunization with hepatitis $\mathrm{C}$ virus-like particles (HCV-LPs) results in the induction of certain $\mathrm{HCV}$-specific cellular immune responses that can control a hepatitis $\mathrm{C}$ virus infection in chimpanzees [74]. Another study in baboons found that after a course of treatment with HCV-LPs all the animals exhibited an HCV-specific immune response and developed antibodies to HCV proteins [75].

\section{rDNA and adenovirus vaccines}

The induction of long-term HCV-specific antibody and Tcell responses was demonstrated in chimpanzees as a result of immunization with recombinant DNA and adenovirus vaccines expressing HCV core, E1E2, and NS3-5 genes; a substantial reduction in the viral load was also observed [76]. 


\section{Dendritic cells transduced with an adenovirus encoding NS3 protein}

This is a new immunization approach using dendritic cells, the most potent antigen presenting cells, loaded with viral antigens to induce antiviral immunity [77,78]. Other immunomodulatory agents and vaccines are currently in clinical trials [79].

\section{Prevention and control of HCV}

The Centers for Disease Control and Prevention (CDC) recommend implementing primary and secondary prevention activities in order to control the spread of $\mathrm{HCV}$ [80]. Primary prevention activities include virus inactivation in blood products, testing organ and tissue donors, and providing counseling on risk reduction $[5,80]$. These activities aim to reduce the risk of contracting HCV through the main transmission routes, including the use of contaminated drug needles, engaging in sexual intercourse with infected persons, and percutaneous exposure to infected blood in the health care and other (e.g. tattooing and body piercing) fields [80]. Secondary prevention activities, such as counseling, identifying and testing people at risk, and treating infected patients, are intended to reduce the risks for liver and other chronic diseases in those patients infected with HCV $[5,80]$. Providing education for healthcare professionals and the general public, along with surveillance and research to monitor disease trends are also parts of the comprehensive strategy recommended by the CDC [80].

\section{Conclusions}

Although great advances have been made in the development of immunotherapies for $\mathrm{HCV}$, this field is challenged by the lack of adequate knowledge of the virus and its interaction with the host cells. One of the reasons for these difficulties is the absence of a simple animal model for the disease, as only chimpanzees can be used for this purpose. The results of several studies on the development of effective vaccines and powerful antivirals show that more and highly effective protective treatment options will be available in the near future. The current standard for care, according to the American Association for the Study of Liver Diseases and European guidelines, is a combination of pegylated IFN and ribavirin with or without a protease inhibitor in patients with genotype 1 infection, taking note that these should be prescribed with caution due to the discovery of resistant strains. Other factors that may influence response to therapy, such as HDL levels, serum vitamin D levels, IL-28B genotype, viral load and genotype, and RVR/ cEVR, should be taken into consideration. Implementing various prevention and control strategies, promptly identifying and treating acutely infected individuals, creating public awareness of the disease, and continuing $\mathrm{HCV}$ research should all be of the highest importance.

\section{Recently published phase lla data for successful HCV genotype 1 treatment with two antiviral agents for patients who previously did not respond to peginterferon and ribavirin therapy}

Results reported since peer review of this article showed a SVR was achieved in HCV genotype 1 patients treated with only two antiviral agents (asunaprevir and daclatasvir), and that a high rate of SVR was obtained when these two agents were combined with peginterferon alfa-2a and ribavirin, at 12 weeks after treatment. Notably, the success rate was $100 \%$ in patients receiving the combination therapy of the two antivirals plus peginterferon alfa-2a and ribavirin [81].

\section{Abbreviations}

ALT: Alanine aminotransferase; AASLD: American Association for the Study of Liver Disease; CEVR: Complete early virological response; CyPB: Cyclophilin B; EACS: European AIDS Clinical Society; HCV: Hepatitis C virus; HCV-LPs: Hepatitis C virus-like particles; IFN: Interferon; peg-IFN: Pegylated interferon; RVR: Rapid virological response; SVR: Sustained virologic response; TLR: Tolllike receptor

\section{Author details}

${ }^{1}$ The Pharmaceutical Research Institute, Albany College of Pharmacy and Health Sciences, Rensselaer, NY, USA. Faculty of Medicine, Almansoura University, Almansoura, Egypt.

\section{Authors' contributions}

WA performed literature searches and drafted the manuscript. SM and GS participated in editing the manuscript and in particular SM added text based on the reviewers' comments. SAM participated in drafting the outline and editing of the manuscript. All authors read and approved the final manuscript.

\section{Competing interests}

The authors declare that they have no competing interests.

Received: 10 August 2011 Accepted: 2 March 2012

Published: 2 March 2012

\section{References}

1. Czepiel J, Biesiada G, Mach T: Viral hepatitis C. Pol Arch Med Wewn 2008, 118:734-740

2. Saadeh S, Davis GL: The evolving treatment of chronic hepatitis C: where we stand a decade out. Cleve Clin J Med 2004, 71(Suppl 3):S3-7.

3. Gryseels B, Polman K, Clerinx J, Kestens L: Human schistosomiasis. Lancet 2006, 368:1106-1118

4. Sharma SD: Hepatitis C virus: molecular biology \& current therapeutic options. Indian J Med Res 2010, 131:17-34

5. Global Alert and Response (GAR), Hepatitis C. World Health Organization 2002.

6. Sarasin-Filipowicz M: Interferon therapy of hepatitis C: molecular insights into success and failure. Swiss Med Wkly 2010, 140:3-11.

7. Hepatitis C, Acute: Case definition. [http://www.cdc.gov/ncphi/disss/ nndss/casedef/hepatitiscacutecurrent.htm]

8. Caruntu FA, Benea L: Acute hepatitis C virus infection: Diagnosis, pathogenesis, treatment. J Gastrointestin Liver Dis 2006, 15:249-256.

9. DiPiro JT, Talbert RL, Yee GC, Matzke GR, Wells BG, Posey LM: Pharmacotherapy A pathophysiologic Approach. 7 edition. McGraw-Hill Medical; 2008 
10. Falck-Ytter Y, Kale H, Mullen KD, Sarbah SA, Sorescu L, McCullough AJ: Surprisingly small effect of antiviral treatment in patients with hepatitis C. Ann Intern Med 2002, 136:288-292.

11. Hu J, Doucette K, Hartling L, Tjosvold L, Robinson J: Treatment of hepatitis C in children: a systematic review. PLoS One 2010, 5:e11542.

12. Danish FA, Koul SS, Subhani FR, Rabbani AE, Yasmin S: Managing HCV infection in pediatric age group: suggested recommendations. Saudi J Gastroenterol 2010, 16:230-235.

13. Hickman IJ, Jonsson JR, Prins JB, Ash S, Purdie DM, Clouston AD, Powell EE: Modest weight loss and physical activity in overweight patients with chronic liver disease results in sustained improvements in alanine aminotransferase, fasting insulin, and quality of life. Gut 2004, 53:413-419.

14. Hourigan LF, Macdonald GA, Purdie D, Whitehall VH, Shorthouse C, Clouston A, Powell EE: Fibrosis in chronic hepatitis $C$ correlates significantly with body mass index and steatosis. Hepatology 1999, 29:1215-1219.

15. Mas VR, Fassnacht R, Archer KJ, Maluf D: Molecular mechanisms involved in the interaction effects of alcohol and hepatitis $C$ virus in liver cirrhosis. Mol Med 2010, 16:287-297.

16. McCartney EM, Beard MR: Impact of alcohol on hepatitis C virus replication and interferon signaling. World J Gastroenterol 2010, 16:1337-1343.

17. Fujita Y, Shibata A, Ogimoto I, Kurozawa Y, Nose T, Yoshimura T, Suzuki H, Iwai N, Sakata R, Ichikawa S, Tamakoshi A: The effect of interaction between hepatitis $C$ virus and cigarette smoking on the risk of hepatocellular carcinoma. Br J Cancer 2006, 94:737-739.

18. Sharaf Eldin N, Ismail S, Mansour H, Rekacewicz C, El-Houssinie M, ElKafrawy S, El Aidi S, Abdel-Hamid M, Esmat G, Pol S, Fontanet A, Mohamed MK: Symptomatic acute hepatitis $C$ in Egypt: diagnosis, spontaneous viral clearance, and delayed treatment with 12 weeks of pegylated interferon alfa-2a. PLoS One 2008, 3:e4085.

19. Kamal SM, Fouly AE, Kamel RR, Hockenjos B, Al Tawil A, Khalifa KE, He Q, Koziel MJ, El Naggar KM, Rasenack J, Afdhal NH: Peginterferon alfa-2b therapy in acute hepatitis C: impact of onset of therapy on sustained virologic response. Gastroenterology 2006, 130:632-638.

20. Gerlach JT, Diepolder HM, Zachoval R, Gruener NH, Jung MC, Ulsenheimer A, Schraut WW, Schirren CA, Waechtler M, Backmund M, Pape GR: Acute hepatitis C: high rate of both spontaneous and treatment-induced viral clearance. Gastroenterology 2003, 125:80-88.

21. Lexi-Drugs Online: Peginterferon Alfa-2b. Lexi-Comp, Inc.; 2010.

22. Zeuzem S, Feinman SV, Rasenack J, Heathcote EJ, Lai MY, Gane E, O'Grady J, Reichen J, Diago M, Lin A, Hoffman J, Brunda MJ: Peginterferon alfa-2a in patients with chronic hepatitis C. N Engl J Med 2000, 343:1666-1672.

23. Liu CH, Liang CC, Lin JW, Chen SI, Tsai HB, Chang CS, Hung PH, Kao JH, Liu CJ, Lai MY, Chen JH, Chen PJ, Chen DS: Pegylated interferon alpha-2a versus standard interferon alpha-2a for treatment-naive dialysis patients with chronic hepatitis C: a randomised study. Gut 2008, 57:525-530.

24. Heathcote EJ, Shiffman ML, Cooksley WG, Dusheiko GM, Lee SS, Balart L, Reindollar R, Reddy RK, Wright TL, Lin A, Hoffman J, De Pamphilis J: Peginterferon alfa-2a in patients with chronic hepatitis $C$ and cirrhosis. $N$ Engl J Med 2000, 343:1673-1680.

25. Silva $M$, Poo J, Wagner $F$, Jackson $M$, Cutler $D$, Grace $M$, Bordens $R$, Cullen C, Harvey J, Laughlin M: A randomised trial to compare the pharmacokinetic, pharmacodynamic, and antiviral effects of peginterferon alfa- $2 \mathrm{~b}$ and peginterferon alfa-2a in patients with chronic hepatitis C (COMPARE). J Hepatol 2006, 45:204-213.

26. Berenguer J, Gonzalez-Garcia J, Lopez-Aldeguer J, Von-Wichmann MA, Quereda C, Hernando A, Sanz J, Tural C, Ortega E, Mallolas J, Santos I, Miralles P, Montes ML, Bellon JM, Esteban $\mathrm{H}$ : Pegylated interferon \{alpha\} $2 a$ plus ribavirin versus pegylated interferon \{alpha\}2b plus ribavirin for the treatment of chronic hepatitis C in HIV-infected patients. Antimicrob Chemother 2009, 63:1256-1263.

27. Crotty S, Maag D, Arnold JJ, Zhong W, Lau JY, Hong Z, Andino R, Cameron CE: The broad-spectrum antiviral ribonucleoside ribavirin is an RNA virus mutagen. Nat Med 2000, 6:1375-1379.

28. Leyssen P, Balzarini J, De Clercq E, Neyts J: The predominant mechanism by which ribavirin exerts its antiviral activity in vitro against flaviviruses and paramyxoviruses is mediated by inhibition of IMP dehydrogenase. $J$ Virol 2005, 79:1943-1947.

29. Di Bisceglie AM, Conjeevaram HS, Fried MW, Sallie R, Park Y, Yurdaydin C, Swain M, Kleiner DE, Mahaney K, Hoofnagle JH: Ribavirin as therapy for chronic hepatitis C. A randomized, double-blind, placebo-controlled trial. Ann Intern Med 1995, 123:897-903.

30. Dusheiko G, Main J, Thomas H, Reichard O, Lee C, Dhillon A, Rassam S, Fryden A, Reesink H, Bassendine M, Norkrans G, Cuypers T, Lelie N, Telfer P, Watson J, Weegink C, Sillikens P, Weiland O: Ribavirin treatment for patients with chronic hepatitis C: results of a placebo-controlled study. J Hepatol 1996, 25:591-598.

31. Hoofnagle JH, Lau D, Conjeevaram H, Kleiner D, Di Bisceglie AM: Prolonged therapy of chronic hepatitis C with ribavirin. J Viral Hepat 1996, 3:247-252.

32. Shiffman ML: What future for ribavirin? Liver Int 2009, 29(Suppl 1):68-73.

33. Dienstag JL, McHutchison JG: American Gastroenterological Association technical review on the management of hepatitis C. Gastroenterology 2006, 130:231-264, quiz 214-237.

34. Manns MP, McHutchison JG, Gordon SC, Rustgi VK, Shiffman M, Reindollar R, Goodman ZD, Koury K, Ling M, Albrecht JK: Peginterferon alfa- $2 \mathrm{~b}$ plus ribavirin compared with interferon alfa- $2 \mathrm{~b}$ plus ribavirin for initial treatment of chronic hepatitis C: a randomised trial. Lancet 2001, 358:958-965.

35. Hadziyannis SJ, Sette H Jr, Morgan TR, Balan V, Diago M, Marcellin P, Ramadori G, Bodenheimer H Jr, Bernstein D, Rizzetto M, Zeuzem S, Pockros PJ, Lin A, Ackrill AM: Peginterferon-alpha2a and ribavirin combination therapy in chronic hepatitis C: a randomized study of treatment duration and ribavirin dose. Ann Intern Med 2004, 140:346-355.

36. Petta S, Camma C, Scazzone C, Tripodo C, Di Marco V, Bono A, Cabibi D Licata G, Porcasi R, Marchesini G, Craxi A: Low vitamin D serum level is related to severe fibrosis and low responsiveness to interferon-based therapy in genotype 1 chronic hepatitis C. Hepatology 2010, 51:1158-1167.

37. Abu Mouch S, Fireman Z, Jarchovsky J, N Assy N: Vitamin D supplement improve SVR in chronic hepatitis C (genotype 1) naive patients treated with peg interferon and ribavirin. 45th Annual Meeting of the European Association for the Study of the Liver (EASL 2010) Vienna, Austria; 2010.

38. Lee SS, Heathcote EJ, Reddy KR, Zeuzem S, Fried MW, Wright TL, Pockros PJ, Haussinger D, Smith Cl, Lin A, Pappas SC: Prognostic factors and early predictability of sustained viral response with peginterferon alfa-2a (40KD). J Hepatol 2002, 37:500-506.

39. Ferenci P, Fried MW, Shiffman ML, Smith Cl, Marinos G, Goncales FL Jr, Haussinger D, Diago M, Carosi G, Dhumeaux D, Craxi A, Chaneac M, Reddy KR: Predicting sustained virological responses in chronic hepatitis $\mathrm{C}$ patients treated with peginterferon alfa-2a (40 KD)/ribavirin. $J$ Hepatol 2005, 43:425-433

40. Layden TJ, Layden JE, Reddy KR, Levy-Drummer RS, Poulakos J, Neumann AU: Induction therapy with consensus interferon (CIFN) does not improve sustained virologic response in chronic hepatitis C. J Viral Hepat 2002, 9:334-339.

41. Rodriguez-Torres M, Sulkowski MS, Chung RT, Hamzeh FM, Jensen DM: Factors associated with rapid and early virologic response to peginterferon alfa-2a/ribavirin treatment in HCV genotype 1 patients representative of the general chronic hepatitis $C$ population. J Viral Hepat 2010, 17:139-147.

42. Flamm S, Lawitz E, Jacobson I, Rubin R, Bourliere M, Hezode C, Vierling J, Niederau C, Sherman M, Goteti V, Vilchez R, Brass C, Albrecht J, Poordad F: High sustained virologic response (SVR) among genotype 1 previous non-responders and relapsers to peginterferon/ribavirin when re-treated with boceprevir $(\mathrm{BOC})$ plus peginterferon alfa-2a/ribavirin. The International Liver Congress ${ }^{\mathrm{TM}} 2011$ by EASL (46th annual meeting) Berlin, Germany; 2011.

43. Zeuzem S, Andreone P, Pol S, Lawitz EJ, Diago M, Roberts S, Focaccia R, Younossi ZM, Foster GR, Horban APPJ, Van Heeswijk R, de Meyer S, Luo S, Picchio G, Beumont M: Telaprevir-based regimen for genotype 1 hepatitis $C$ virus infection in patients with prior null response, partial response or relapse to peginterferon/ribavirin. The International Liver Congress ${ }^{\mathrm{TM}} 2011$ by EASL (46th annual meeting) Berlin, Germany; 2011.

44. Jacobson IM, Catlett I, Marcellin P, Bzowej NH, Muir AJ, Adda N, Bengtsson L, George S, Seepersaud S, Ramachandran R, Sussky K, Kauffman RS, Botfield M: Telaprevir substantially improved SVR rates across all IL28B genotypes in the ADVANCE trial. The International Liver Congress ${ }^{\mathrm{TM}} 2011$ by EASL (46th annual meeting) Berlin, Germany; 2011.

45. Forestier N, Reesink HW, Weegink CJ, McNair L, Kieffer TL, Chu HM, Purdy S, Jansen PL, Zeuzem S: Antiviral activity of telaprevir (VX-950) and peginterferon alfa-2a in patients with hepatitis C. Hepatology 2007, 46:640-648. 
46. Hezode C, Forestier N, Dusheiko G, Ferenci P, Pol S, Goeser T, Bronowicki JP, Bourliere M, Gharakhanian S, Bengtsson L, McNair L, George S, Kieffer T, Kwong A, Kauffman RS, Alam J, Pawlotsky JM, Zeuzem S: Telaprevir and peginterferon with or without ribavirin for chronic HCV infection. N Engl J Med 2009, 360:1839-1850.

47. McHutchison JG, Everson GT, Gordon SC, Jacobson IM, Sulkowski M, Kauffman R, McNair L, Alam J, Muir AJ: Telaprevir with peginterferon and ribavirin for chronic HCV genotype 1 infection. N Engl J Med 2009, 360:1827-1838.

48. Jacobson IM, McHutchison JG, Dusheiko G, Di Bisceglie AM, Reddy KR, Bzowej NH, Marcellin P, Muir AJ, Ferenci P, Flisiak R, George J, Rizzetto M, Shouval D, Sola R, Terg RA, Yoshida EM, Adda N, Bengtsson L, Sankoh AJ, Kieffer TL, George S, Kauffman RS, Zeuzem S: Telaprevir for previously untreated chronic hepatitis C virus infection. N Engl J Med 2011, 364:2405-2416.

49. Flint M, Mullen S, Deatly AM, Chen W, Miller LZ, Ralston R, Broom C, Emini EA, Howe AY: Selection and characterization of hepatitis $C$ virus replicons dually resistant to the polymerase and protease inhibitors HCV-796 and boceprevir (SCH 503034). Antimicrob Agents Chemother 2009, 53:401-411.

50. Malcolm BA, Liu R, Lahser F, Agrawal S, Belanger B, Butkiewicz N, Chase R, Gheyas F, Hart A, Hesk D, Ingravallo P, Jiang C, Kong R, Lu J, Pichardo J, Prongay A, Skelton A, Tong X, Venkatraman S, Xia E, Girijavallabhan V, Njoroge FG: SCH 503034, a mechanism-based inhibitor of hepatitis C virus NS3 protease, suppresses polyprotein maturation and enhances the antiviral activity of alpha interferon in replicon cells. Antimicrob Agents Chemother 2006, 50:1013-1020

51. Bacon BR, Gordon SC, Lawitz E, Marcellin P, Vierling JM, Zeuzem S, Poordad F, Goodman ZD, Sings HL, Boparai N, Burroughs M, Brass CA, Albrecht JK, Esteban R: Boceprevir for previously treated chronic HCV genotype 1 infection. N Engl J Med 2011, 364:1207-1217.

52. Poordad F, McCone J Jr, Bacon BR, Bruno S, Manns MP, Sulkowski MS, Jacobson IM, Reddy KR, Goodman ZD, Boparai N, DiNubile MJ, Sniukiene V, Brass CA, Albrecht JK, Bronowicki JP: Boceprevir for untreated chronic HCV genotype 1 infection. N Engl J Med 2011, 364:1195-1206.

53. Chevaliez S, Rodriguez C, Soulier A, Ahmed-Belkacem A, Hezode C, Pawlotsky JM: Molecular characterization of HCV resistance to telaprevir by means of ultra-deep pyrosequencing: pre-existing resistant variants and dynamics of resistant populations. The International Liver Congress ${ }^{\mathrm{TM}}$ 2011 by EASL (46th annual meeting) Berlin, Germany; 2011.

54. Svarovskaia ES, Martin R, Miller MD, Mo H: Abundant Minority Drug-Resistant NS3 Mutants Detected by Deep Sequencing in HCV Patients as Early as 24 Hours After Intiating Antiviral Treatment In The International Liver Congress ${ }^{\mathrm{TM}}$ 2011 by EASL (46th annual meeting) Germany: Berlin; 2011.

55. Sullivan JC, De Meyer S, Bartels DJ, Dierynck I, Zhang E, Spanks J, Tigges A, Adda N, Martin EC, Beumont M, Jacobson IM, Sherman KE, Zeuzem S, Picchio G, Kieffer TL: Evolution of Treatment-Emergent Resistant Variants in Telaprevir Phase 3 Clinical Trials. The International Liver Congress ${ }^{\mathrm{TM}} 2011$ by EASL (46th annual meeting) Berlin, Germany; 2011.

56. De Francesco R, Migliaccio G: Challenges and successes in developing new therapies for hepatitis C. Nature 2005, 436:953-960

57. Brau N: Treatment of chronic hepatitis $\mathrm{C}$ in human immunodeficiency virus/hepatitis C virus-coinfected patients in the era of pegylated interferon and ribavirin. Semin Liver Dis 2005, 25:33-51.

58. Vellozzi C, Buchacz K, Baker R, Spradling PR, Richardson J, Moorman A, Tedaldi E, Durham M, Ward J, Brooks JT: Treatment of hepatitis $C$ virus $(\mathrm{HCV})$ infection in patients coinfected with HIV in the HIV Outpatient Study (HOPS), 1999-2007. J Viral Hepat 2011, 18:316-324.

59. European Treatment Guidelines. [http://www.europeanaidsclinicalsociety $\mathrm{org} /]$.

60. Ghany MG, Nelson DR, Strader DB, Thomas DL, Seeff LB: An update on treatment of genotype 1 chronic hepatitis $C$ virus infection: 2011 practice guideline by the American Association for the study of liver diseases. Hepatology 2011, 54:1433-1444.

61. Manns MP, Foster GR, Rockstroh JK, Zeuzem S, Zoulim F, Houghton M: The way forward in HCV treatment-finding the right path. Nat Rev Drug Discov 2007, 6:991-1000.

62. Salomon JA, Weinstein MC, Hammitt JK, Goldie SJ: Cost-effectiveness of treatment for chronic hepatitis $\mathrm{C}$ infection in an evolving patient population. JAMA 2003, 290:228-237.
63. Siebert U, Sroczynski G: Effectiveness and cost-effectiveness of initial combination therapy with interferon/peginterferon plus ribavirin in patients with chronic hepatitis $\mathrm{C}$ in Germany: a health technology assessment commissioned by the German Federal Ministry of Health and Social Security. Int J Technol Assess Health Care 2005, 21:55-65.

64. Malone DC, Tran TT, Poordad FF: Cost-efficacy analysis of peginterferon alfa- $2 \mathrm{~b}$ plus ribavirin compared with peginterferon alfa-2a plus ribavirin for the treatment of chronic hepatitis C. J Manag Care Pharm 2005, 11:687-694.

65. Stepanova M, Kanwal F, El-Serag HB, Younossi ZM: Insurance status and treatment candidacy of hepatitis $C$ patients: analysis of populationbased data from the United States. Hepatology 2011, 53:737-745.

66. Watashi K, Ishii N, Hijikata M, Inoue D, Murata T, Miyanari Y, Shimotohno K: Cyclophilin B is a functional regulator of hepatitis C virus RNA polymerase. Mol Cell 2005, 19:111-122.

67. Coelmont L, Kaptein S, Paeshuyse J, Vliegen I, Dumont JM, Vuagniaux G Neyts J: Debio 025, a cyclophilin binding molecule, is highly efficient in clearing hepatitis $\mathrm{C}$ virus (HCV) replicon-containing cells when used alone or in combination with specifically targeted antiviral therapy for HCV (STAT-C) inhibitors. Antimicrob Agents Chemother 2009, 53:967-976.

68. Hopkins S, Huang Z, Murray MG, Wring S, Smitley C, Harris R, Erdmann F, Fischer G, Ribeill Y: SCY-635, a novel nonimmunosuppressive analog of cyclosporine that exhibits potent inhibition of hepatitis $C$ virus RNA replication in vitro. Antimicrob Agents Chemother 2009, 54:660-672.

69. McHutchison JG, Bacon BR, Gordon SC, Lawitz E, Shiffman M, Afdhal NH, Jacobson IM, Muir A, Al-Adhami M, Morris ML, Lekstrom-Himes JA, Efler SM, Davis HL: Phase 1B, randomized, double-blind, dose-escalation trial of CPG 10101 in patients with chronic hepatitis C virus. Hepatology 2007, 46:1341-1349.

70. Horsmans Y, Berg T, Desager JP, Mueller T, Schott E, Fletcher SP, Steffy KR, Bauman LA, Kerr BM, Averett DR: Isatoribine, an agonist of TLR7, reduces plasma virus concentration in chronic hepatitis C infection. Hepatology 2005, 42:724-731.

71. Keeffe EB, Rossignol JF: Treatment of chronic viral hepatitis with nitazoxanide and second generation thiazolides. World I Gastroenterol 2009, 15:1805-1808.

72. Rossignol JF, Kabil SM, El-Gohary Y, Elfert A, Keeffe EB: Clinical trial: randomized, double-blind, placebo-controlled study of nitazoxanide monotherapy for the treatment of patients with chronic hepatitis $C$ genotype 4. Aliment Pharmacol Ther 2008, 28:574-580.

73. Korba BE, Montero AB, Farrar K, Gaye K, Mukerjee S, Ayers MS, Rossignol JF: Nitazoxanide, tizoxanide and other thiazolides are potent inhibitors of hepatitis B virus and hepatitis C virus replication. Antiviral Res 2008, 77:56-63.

74. Elmowalid GA, Qiao M, Jeong SH, Borg BB, Baumert TF, Sapp RK, Hu Z, Murthy K, Liang TJ: Immunization with hepatitis $C$ virus-like particles results in control of hepatitis $\mathrm{C}$ virus infection in chimpanzees. Proc Natl Acad Sci USA 2007, 104:8427-8432.

75. Jeong SH, Qiao M, Nascimbeni M, Hu Z, Rehermann B, Murthy K, Liang TJ: Immunization with hepatitis $C$ virus-like particles induces humoral and cellular immune responses in nonhuman primates. J Virol 2004, 78:6995-7003.

76. Youn JW, Park SH, Lavillette D, Cosset FL, Yang SH, Lee CG, Jin HT, Kim CM, Shata MT, Lee DH, Pfahler W, Prince AM, Sung YC: Sustained E2 antibody response correlates with reduced peak viremia after hepatitis $C$ virus infection in the chimpanzee. Hepatology 2005, 42:1429-1436.

77. Zabaleta A, Llopiz D, Arribillaga L, Silva L, Riezu-Boj Jl, Lasarte JJ, BorrasCuesta F, Prieto J, Sarobe P: Vaccination against hepatitis $C$ virus with dendritic cells transduced with an adenovirus encoding NS3 protein. Mol Ther 2008, 16:210-217.

78. Yu H, Huang $H$, Xiang J, Babiuk LA, van Drunen Littel-van den Hurk S: Dendritic cells pulsed with hepatitis C virus NS3 protein induce immune responses and protection from infection with recombinant vaccinia virus expressing NS3. J Gen Virol 2006, 87:1-10.

79. Forde KA, Reddy KR: Hepatitis C virus infection and immunomodulatory therapies. Clin Liver Dis 2009, 13:391-401.

80. In Recommendations for Prevention and Control of Hepatitis C Virus (HCV) Infection and HCV-Related Chronic Disease. Volume 47. Edited by: Services DoHaH. Atlanta: Morbidity and Mortality Weekly Report, Centers for Disease Control and Prevention; 1998:1-39. 
81. Lok AS, Gardiner DF, Lawitz E, Martorell C, Everson GT, Ghalib R, Reindollar R, Rustgi V, McPhee F, Wind-Rotolo M, Persson A, Zhu K, Dimitrova DI, Eley T, Guo T, Grasela DM, Pasquinelli C: Preliminary study of two antiviral agents for hepatitis C genotype 1. N Engl J Med 2012, 366(3):216-224.

doi:10.1186/1743-422X-9-57

Cite this article as: Aman et al.: Current status and future directions in the management of chronic hepatitis C. Virology Journal 2012 9:57.

Submit your next manuscript to BioMed Central and take full advantage of:

- Convenient online submission

- Thorough peer review

- No space constraints or color figure charges

- Immediate publication on acceptance

- Inclusion in PubMed, CAS, Scopus and Google Scholar

- Research which is freely available for redistribution

Submit your manuscript at www.biomedcentral.com/submit 